\title{
El bileği fleksör tendonlarında tüberküloz tenosinoviti
}

\author{
Melike DEMiR ${ }^{1}$ \\ Levent KÜÇÜK ${ }^{2}$ \\ Gülşen MERMUT ${ }^{1}$ \\ Hüsnü PULLUKÇU ${ }^{1}$ \\ Cengiz ÇAVUŞOĢLU ${ }^{3}$ \\ Meltem IŞIKGÖZ \\ TAŞBAKAN ${ }^{1}$
}

\footnotetext{
${ }^{1}$ Ege Üniversitesi Tıp Fakültesi, İnfeksiyon Hastalıkları ve Klinik Mikrobiyoloji Anabilim Dalı, İzmir, Türkiye

${ }^{1}$ Department of Infectious Diseases and Clinical Microbiology, Faculty of Medicine, Ege University, Izmir, Turkey

2 Ege Üniversitesi Tıp Fakültesi, Ortopedi ve Travmatoloji Anabilim Dalı, İzmir, Türkiye

2 Department of Orthopedics and Traumatology, Faculty of Medicine, Ege University, Izmir, Turkey

${ }^{3}$ Ege Üniversitesi Tıp Fakültesi, Tıbbi Mikrobiyoloji Anabilim Dalı, İzmir, Türkiye

${ }^{3}$ Department of Medical Microbiology, Faculty of Medicine, Ege University, Izmir, Turkey
}

$\begin{aligned} & \text { Makale atıfı: Demir M, Küçük L, Mermut G, Pullukçu } \\ & \text { H, Çavuşoğlu C, Işıkgöz Taşbakan M. El bileği fleksör } \\ & \text { tendonlarında tüberküloz tenosinoviti. Tuberk Toraks } \\ & \text { 2019;67(3):236-8. }\end{aligned}$
Yazışma Adresi (Address for Correspondence)
Dr. Melike DEMiR
Ege Üniversitesi Tıp Fakültesi,
Infeksiyon Hastalıkları ve Klinik Mikrobiyoloji
Anabilim Dalı, iZMiR - TÜRKiYE
e-mail: mlkdmr13@gmail.com

OTelif Hakkı 2019 Tüberküloz ve Toraks. Makale metnine www.tuberktoraks.org web adresinden ulaşılabilir.
Tüberküloz (TB), tüm doku ve organları tutabilen bir infeksiyon hastalığıdır. Dünyadaki ölümlerin ilk 10 sebebinden biri olmaya devam eden TB nedeniyle 2017 yılında 300 bini insan immünyetmezlik virüsü (HIV) pozitif olmak üzere 1.6 milyon kişi hayatını kaybetmiştir. Bu ölümlerin \%95'i düşük ve orta gelirli ülkelerde olmuştur (1). Sağlık Bakanlığı Verem Savaşı 2018 Raporuna göre ülkemizde 2005-2016 yılları arasında akciğer TB'si olgularında azalma gözlenmiş, ancak akciğer dışı TB sıklığı \%27'den \%33.6'ya yükselmiştir (2).

Akciğer dışı TB, primer akciğer infeksiyonu ile beraber akut olarak görülebilmekle birlikte, primer infeksiyondan yıllar sonra reaktivasyon infeksiyonu olarak da görülebilir. Akciğer dışı TB'nin başlıca tutulum yerleri miliyer TB, TB menenjit, TB lenfadenit, kemik-eklem TB'si, plevra ve perikart TB'si, genitoüriner TB ve gastrointestinal TB'dir. Kemik-eklem TB'si nadir görülen bir TB şeklidir. Genellikle monoartiküler olup; vertebra, kalça, diz gibi vücut ağırlığını taşıyan eklemlerde görülür. Sıklıkla birincil odaktan hematojen yayılım ile ortaya çıkar. Olguların \%29'unda eşlik eden akciğer tutulumu vardır (3).

Özellikle TB elde nadir olarak görülen, ağrısız şişlik, tenosinovit, hareket kısıtıılığı ve bazen kompresif nöropati ile karakterize olabilen bir infeksiyon hastalığıdır. Yavaş ilerleyen semptomlar tanı- 
nın geç konmasına ve tedavinin gecikmesine neden olur. TB tanısı karakteristik histopatolojik bulgular, kültürde ve/veya aside dirençli boyamada pozitif sonuç ve moleküler yöntemlerle konulur. Tanıda altın standart açık biyopsi ile örnekleme yapılarak mikobakteriyolojik kültürde üremenin gösterilmesidir (4). Endemik bölgelerde klinik ve radyolojik bulgular ile hastalıktan şüphe edildiğinde kültür pozitifliğine ihtiyaç duyulmadan tedavi başlanabilir (5). TB infeksiyonunun tedavisinde medikal tedavi esastır. Cerrahi tedavi aşırı sinovite bağlı şişlik ve nöropati bulgularının eşlik ettiği ileri olgularda uygulanır. Bu yazıda nadir bir tutulum olarak karşımıza çıkan el bileğinde TB tenosinoviti olgusu sunulmuştur.

Kronik hastalık ve ilaç kullanımı öyküsü olmayan 44 yaşındaki erkek hastanın, başvurusundan yedi ay önce hayvan kesimi esnasında kemik ile sol elde kesi olmuş, üç gün içerisinde kendiliğinden iyileşmiş ancak iki ay sonra elde şişlik, ağrı şikayeti gelişmiş ve ortopedi hekimine başvurmuş. Yapılan manyetik rezonans görüntüleme tetkikinde fleksör tendon komşuluğunda yaygın nonspesifik inflamatuvar tenosinovit saptanan hastaya debridman uygulanmıs. Operasyonda alınan örnekler bakteriyoloji, mikoloji, mikobakteriyoloji ve patoloji birimine gönderilmiş. Histopatolojik incelemede geniş alanlarda epiteloid histiyositlerin oluşturduğu irili ufaklı granülom yapıları, granülomların etrafında lenfosit popülasyonu, seyrek Langerhans hücresi görülmüş olup olgunun TB başta olmak üzere granülomatöz hastalıklar yönünden araştırılması önerilmiş. Doku örneğinden hazırlanan yaymanın mikroskobik incelemesinde aside dirençli basil (ARB) görülmeyen ancak örneklerin MGIT960 (Becton Dickinson, $\mathrm{ABD}$ ) besiyerinde yapılan kültürlerinde Mycobacterium tuberculosis kompleks üremesi saptanan hasta tarafımıza yönlendirilmiş. Ayrıntılı sorgulamasında sistemik bulgu, ateş yüksekliği, kilo kaybı olmadığı öğrenildi. İnterferon gama salınım testi pozitif sonuçlanan olgunun primer odak açısından yapılan akciğer görüntülemesinde patolojik bulgu saptanmadı. Bruselloz açısından yapılan incelemede rose bengal zayıf pozitif bulunurken standart Wright aglütinasyon testinde < 1/80 titrede pozitiflik saptandı. Biyokimyasal tetkiklerinde karaciğer ve böbrek fonksiyon testleri olağan sınırlarda, C-reaktif protein ve sedimentasyon yüksekliği bulunmayan, anti-HIV testi negatif olan olguya iki ay süreyle izoniazid $300 \mathrm{mg} / \mathrm{gün}$, rifampisin $600 \mathrm{mg} /$ gün, pirazinamid $2000 \mathrm{mg} /$ gün ve etambutol 1500 $\mathrm{mg} /$ gün devamında izoniazid ve rifampisin verilerek toplam tedavi süresinin dokuz aya tamamlanması planlandı. İzlem sırasında MGIT960 sisteminde yapılan primer anti-TB ilaç duyarlılık testlerinde kullanılan ilaçlara direnç saptanmadığı bildirildi.

M. tuberculosis'e bağlı gelişen tendon kılıfı infeksiyonu, akciğer dışı TB'nin nadir bir formudur. TB tenosinovit olguları, tüm kas iskelet TB'si olgularının $\% 5$ 'inden azını oluşturur (6). Osteoartiküler TB'nin elde en sık tutulum şekli tenosinovittir. Tendon kılıfı TB'si genellikle el, el bileği, ayak ve ayak bileğinde görülür. El ve el bileğinde fleksör tendon kılıfı ve radioulnar bursa en yaygın tutulan bölgelerdir. Kolaylaştırıcı faktörler travma, immünsüpresyon, malnütrisyon, alkolizm, eklemin aşırı kullanımı, ileri yaş, düşük sosyoekonomik durum ve steroid enjeksiyonlarıdır. Olgumuzda da travma öyküsü ve düşük sosyoekonomik düzey bulunmaktaydı. TB tenosinovit bulgularının nonspesifik olmaları ve sinsi olarak ortaya çıkmalarından dolayı hastalığın tanısı geç konulabilir. Ayırıcı tanılar arasında piyojenik infeksiyonlar, yabanCl cisim tenosinoviti, sarkoidoz, bruselloz, romatoid artrit ve fungal infeksiyonlar sayılabilir (7). Laboratuvar testlerinde sedimentasyon normal ve tüberkülin deri testleri negatif olabilir (8). Negatif deri testi ve akciğer görüntülemesinde patolojik özellik olmaması tanıyı dışlamaya yetmez. Hastalığın nadir görülmesi, laboratuvar testlerinin tanıyı desteklememesi, bulgu ve belirtileri yavaş ilerleyici karakterde olması sebebiyle bu olguların tanısını erken dönemde koymak zordur. Tanının geç konması tedavi gecikmesine ve sinovit tablosunun ilerlemesine neden olabilir. Tenosinovite bağ ı tendonlarda kopma, infeksiyonun kemik ve eklemlere yayılması görülebilir (9). Cerrahi tedavide infekte sinoviyal dokuya radikal eksizyon ve debridman uygulanır. Cerrahi sırasında pirinç tanesi görünümü TB tenosinoviti için tipiktir (10). Elde yavaş gelişen şişlik, hareket kısıtlılığı yaratacak sinovit nedeniyle izlenen hastaların olası tanılarında TB akla getirilmelidir. TB'ye bağlı tenosinovit tanısı büyük oranda klinisyenin bu tanıyı düşünmesi ve klinik şüphe ile konulur. Tedavide asıl olan tanının kısa zamanda konularak erken dönemde medikal tedaviye başlanması ve eğer gerekiyorsa sinovektominin radikal olarak inflame olan tüm dokuları içerecek şekilde yapılmasıdır. Birçok yazar en az dokuz ay süreyle medikal tedavi önermektedir. Akciğer dışı TB hala önemini koruyan bir infeksiyon hastalığı olup atipik tutulumlarda cerrahi planlanan olgularda doku örneklerinin patoloji ve mikobakteriyoloji laboratuvarlarına gönderilmesi tanının erken konulması ve komplikasyonların önlenmesi açısından oldukça önemlidir. 


\section{KAYNAKLAR}

1. WHO Global Tuberculosis Report 2018.

2. Sağıık Bakanlığı Verem Savaşı 2018 Raporu.

3. Pigrau-Serrallach C, Rodríguez-Pardo D. Bone and joint tuberculosis. Eur Spine I 2013;22(Suppl 4):556-66.

4. Malaviya AN, Kotwal PP. Arthritis associated with tuberculosis. Best Pract Res Clin Rheumatol 2003;17:319-43.

5. Al-Qattan MM, Al-Namla A, Al-Thunayan A, Al-Omawi M. Tuberculosis of the hand. I Hand Surg Am 2011;36:141321.

6. Dumontier C, Maylin V, Sautet A, Lenoble E, Urban T, Apoil A. Rupture of the flexor tendon of the hand caused by tuberculosis. Rev Chir Orthop Reparatrice Appar Mot 1996;82:668-71.

7. Hsu CY, Lu HC, Shih TT. Tuberculous infection of the wrist: MRI features. AJR Am J Roentgenol 2004; 183:623-8.

8. Skoll PJ, Hudson DA. Tuberculosis of the upper extremity. Ann Plast Surg 1999;43:374-8.

9. Sungur N, Uysal A, Gümüş $M$, Koçer U, Çaydere $M$, Şahin F. Combined ulnar and median nerve compression due to atypical mycobacterial tenosynovitis: case report. Eur I Plast Surg 2004;27:143-5

10. Suso S, Peidro L, Ramon R. Tuberculosis synovitis with "rice bodies" presenting as carpal tunnel syndrome. I Hand Surg Am 1988;13:574-6. 